\section{The business of the media and health communication}

\author{
Os negócios da mídia e a comunicação da saúde
}

\author{
Los negocios de los medios de comunicación y la \\ comunicación en el ámbito de la salud
}

Rogério Lannes Rocha ${ }^{1}$

the shore of the state of Espírito Santo were gravely compromised. trary to the public interest was the coverage, by newspapers $O$ Globo and Folha de S. Paulo about the worst socioenvironmental disaster in Brazil, which affected the municipality of Mariana, Minas Gerais State, and the entire Doce river valley, caused by mining company Samarco, a joint venture between Brazilian Vale and Anglo-Australian BHP Billiton.

The collapse of the Fundão and Santarém dams, on November 5, 2015, released 62 million cubic meters of mining waste, which fell like a tsunami, dragging along all that was in the way. The first ones to be hit were the workers, and then the population of the Bento Rodrigues district (destroyed by the mudflow) and four other districts of the city of Mariana. The local administration counted 631 displaced by the accident, and, until December 16, 17 deaths (mostly mine workers) and two missing people.

The flood of waste, sediments and toxic substances, such as iron, manganese, barium, lead, zinc, aluminum, chrome, cobalt and arsenic advanced 850 kilometers through the Doce river bed over sixteen days, destroying houses, burying agricultural land, killing fish, silting and compacting river beds and banks, contaminating and making infeasible water treatment and use, impacting the life of hundreds of thousands of people. The Doce river valley ecosystems, dispersed over rural, Indigenous, urban and tropical forest areas and the ecosystem of

\section{Newspapers}

In the first weeks, the $O$ Globo considered the catastrophe a natural phenomenon, and highlighted the support to the people forced out of their homes. The cause of the tragedy was the mud that resulted from an accident, not an environmental crime with causes and responsibilities to be investigated; the focus was diverted to the lack of emergency alarm sounds and evacuation plans. The newspaper kept Vale and BHP on a secondary level, absent from headlines and subtitles. In the peak of the tragedy, it highlighted some older news (November 10 and 13), and contrary to journalistic criteria, no longer placed this subject on the front page (November 11), when 250,000 inhabitants of the city of Governador Valadares despaired over the lack of treated water.

On November 21, the first criticism was printed on the front page: "Samarco ignored requirements". At this point, the toxic waste reached the shore, the company received a fine, the city of Governador Valadares refused 240,000 liters of water Vale sent for the population to use, due to a high kerosene grade. Until that point, only few letters from readers were published, and all of them in line with the paper's point of view. In the 
social networks, from the beginning the paper was strongly criticized, and comparisons were made with the coverage of the recent Paris attacks, and questioned for supporting Vale's proposals to restore the river.

Vale stated, and the $O$ Globo highlighted (December 2) "the loss of millions" with "Samarco's tragedy", that will have to cut investments and will pay "much less taxes" in 2016 due to the price of ore, "political turmoil" in the country, and the financial impact of the "accident". However, the exclusion of the Vale's stock from the 2016 Corporate Sustainability Index (ISE) by BM\&FBovespa, Brazil's stock exchange, was hidden in some lines of an article about the Brazilian Institute of Environment and Renewable Natural Resources (IBAMA) fines paperwork to Samarco.

The Folha de S. Paulo completely minimized the catastrophe, dealing with it as a secondary accident on the first and the internal pages. Two days after the tragedy (November 7), it published a bland headline: "Damages from the sea of mud in MG still uncertain”, and included Samarco's statement that the structure operations were "completely safe". On the first Sunday (November 8), no special article was published, only a teaser with no photo: "In $M G$, there are 5 children among the missing people". On four of the first sixteen days after the tragedy, there was no mention of it on the front page.

Pressured by readers and social networks, $\mathrm{Fo}$ lha de S. Paulo's ombudswoman expressed their mea-culpa (November 22) when she compared their coverage with the ones of $O$ Globo and $O$ Estado de S. Paulo: "there was, indeed, coverage incongruity, and it was even stronger in this paper". She added that, on the first day, Folha did not even mention the names of Vale and BHP but argued that there were other pressing news, " $l i$ ke the Car-Wash Operation (Operação Lava Jato) and the discussions about the impeachment of the president".

Only on November 28 Folha de S. Paulo reported, in a discrete article on an internal page, about the Mariana disaster staining the reputation of BHP Billiton, the world's largest mining company, internationally and mentioned their net profit in 2014: US\$ 4,3 billion; Vale's: US\$ 657 billion; and Samarco's: Brazilian R $\$ 2,8$ billion.

The journalism of these media corporations, in addition to not investigating causes and responsibilities for the tragedy, and to providing late and insufficient heed to the existential desolation and the state of depression of the affected population, ignored other aspects that are dear to public health, such as the way mining companies use scarce resources, such as land and water, and the way they treat the workforce and the popu- lation that lives in the areas where they operate. There was no questioning about the rudimentary techniques that require to use these dams, the predatory mining practices in Brazil, or the lack of socioenvironmental sustainability of the mining development model.

Whether or not media corporations are directly interested in the stocks or in the advertising accounts of these companies, their mission is to work so that the good operations of the market are not shaken. They are aware of the weight of the chosen assignments, highlights, approach and words, published to add or withdraw importance of the companies. They know about the importance of the gap of time between the fact and its disclosure and interpretation, of the convenience of naming a tragedy after the place it occurred, such as Mariana, or after the company that caused it: Union Carbide, in Bhopal, India; Exxon Valdez, in Alaska (USA); Petrobras' rig in Campos basin (Brazil); BP's rig in the gulf of Mexico.

\section{Media}

It was said about the 19th century Parisian press and journalists that their character was to have no character 1, a flaw that has been following newspapers and journalists to date, with the addition of criticisms regarding the manipulating power of the press.

The focus on journalists or on a particular newspaper alone still drives a number of analyses about mass media. The perception of the system that makes up the media, including the typical mass media channels; advertisement; cultural, music-recording and audiovisual industry; internet and telecommunications corporations, information technology companies, and others are left aside. The media system cannot be separated from the economic and political systems.

More than a power to be activated in order to influence opinions, the media is the territory in which power relationships are established, and meanings are made. It mediates and influences settings and rules of contemporary social relations, not as an issuance and orienting center, but as the very environment of conviviality 2 . It is a symbolic territory - and quite concrete, with its technical dispositions - in which the existence of individuals, communities and their institutions takes place and is regulated.

As a system inseparable from the economy and being the hegemonic expression of its time, developed from its core technique and ideology, the media basically reflects the market and the 
capital. The business of the media is, therefore, the businesses.

A critical assessment about processes and products of commercial media corporations, as part of the media complex, should go beyond the job of the journalist or the information conveyed by the press. The business of the media is not journalism, or information. In fact, information is not even media merchandise. It is just part of the assets for the really valuable commodity traded by media corporations, which is attention. What they sell is our attention. In a time information is overflowing, selective attention and diversion of the attention are also high-valued commodities.

Internet and all there is in it, including the interconnections with telecommunications and social networks is basically the space for the excess of information in the media that receives shallow, superficial, dispersed attention, making it unpredictable. That, in addition to the inequalities in the planet, including digital, still confers considerable power to the traditional media. However, there are a number of valuable breaches in the net, the lack of a central discourse and possibilities of cross-sectional articulation and collaboration, which makes it powerful. In the case of Samarco, the discourse of the media was deconstructed in the social networks. However, one should not ignore that the technological bases of the internet are oligopolized and subjected to control.

\section{Public communication, divulgation, research and health}

Proposals advocating the democratization of the media, the universalization of broadband internet access, and the establishment of community radio and television channels on digital $\mathrm{TV}$ were approved in the 15th National Health Conference 3 , in December 2015. The main reason was the discrepancy between reality and what the media says. The assumption is that the assurance of social rights, particularly the right to health, begins with using the right to communications to serve the public interest, as opposed to the media. An inspiration for communications policies and strategies that are emancipated and dialogue with society in public institutions.

A more critical perspective in face of the media may also nurture activities by academia, by observatories and by scientific divulgation. The recognition of the media as a complex environment that regulates life to serve the capital places before research studies an "object" that is not limited to its text or source, nor that exhausts itself in quantitative, disciplinary or decontextualized analysis. To find out how to deal with the flow of attention in the internet is essential to scientific journals, to match the loyalty and credibility of their readers to the interaction and constant updating in the digital environment.

Finally, to study the techno-culture of the media that encompasses and cuts across us will make it possible for us to see more clearly all in life that is not necessarily in the media, such as community and territorial relationships ${ }^{4}$, encounters 5, essential connections and affections 6 , all of which are communication phenomena that are vital for public health.
1. Balzac H. Os jornalistas. Rio de Janeiro: Ediouro; 1999.

2. Sodré M. Antropológica do espelho: uma teoria da comunicação linear e em rede. Petrópolis: Editora Vozes; 2002.

3. Comunicação é estruturante para saúde. Radis 2016; (160).

4. Santos M. Por uma outra globalização: do pensamento único à consciência universal. Rio de Janeiro: Record; 2016.
5. Bubber M. Eu e tu. São Paulo: Centauro; 1977.

6. Rocha R. Em busca do diálogo: um estudo sobre a interatividade na comunicação [Dissertação de Mestrado]. Rio de Janeiro: Escola de Comunicação, Universidade Federal do Rio de Janeiro; 2003.

Submitted on $04 / \mathrm{Jan} / 2016$

Approved on 06/Jan/2016 